\title{
Foreign Policy Analysis and Rational Choice Models
}

Bruce Bueno de Mesquita

New York University/Stanford University

[email address]

[word count]

\section{Introduction}

The study of foreign policy as a rational choice process is undergoing a sea change in its focus and in its impact on policy choices. At least since the end of World War II, foreign policy thinking has been dominated by a realist (or neorealist) perspective in which states are taken as the relevant unit of analysis. There has been a shift away from that orientation within the rational choice community concerned with foreign policy. This has resulted both in the development of game theory models, of direct use in helping to inform foreign policy choices, and in the uncovering of new insights that are reshaping thinking about crucial foreign policy questions. Here I review the relevant literature in terms of its analytic contributions and its place in helping to shape policy decisions. Before doing so, however, I digress briefly to explain the fundamentals behind rational choice models.

\section{What is a Rational Actor Model?}

Although the rational actor perspective on foreign policy has been around for several decades (some early examples include Russett 1967; Brams 1975; Zagare 1977; Altfeld and Bueno de Mesquita 1979; Wittman 1979), misunderstandings and misplaced critiques of the approach persist, hindering thoughtful and informed discussion. With that in mind, I begin with what the rational actor model is not before explaining briefly what it is.

In an otherwise superb study by the historian H.A. Drake (2002), he states concisely common misconceptions of the rational actor model. He writes: 
In its purest form, the Rational Actor approach presumes that such a figure [as Constantine] has complete freedom of action to achieve goals that he or she has articulated through a careful process of rational analysis involving full and objective study of all pertinent information and alternatives. At the same time, it presumes that this central actor is so fully in control of the apparatus of government that a decision once made is as good as implemented. There are no staffs on which to rely, no constituencies to placate, no generals or governors to cajole. By attributing all decision making to one central figure who is always fully in control and who acts only after carefully weighing all options, the Rational Actor method allows scholars to filter out extraneous details and focus attention on central issues. (2002:24)

It is the state-centrism of much international relations scholarship that is behind the survival of caricatures such as Drake's. Since realists drew their core insights by examining the history of European monarchies in the post-Westphalian era, they described a political process that emphasizes the national interest in a way that is reasonably in accord with leadership incentives in fairly centralized monarchies, but not in accord with incentives either in rigged-election autocracies or in democracies, the most common forms of government in the contemporary world (Acemoglu and Robinson 2001; Bueno de Mesquita et al. 2003). That is, they assumed that the desires of the monarch could be equated with the national interest, following the logic of Louis XIV's famous declaration, “L'état c'est moi.” This implicit assumption tends to result in deductions that turn out to be inconsistent with observed patterns of action in contemporary international politics. In contrast, political economy rational actor models that look within as well as between states provide insights into foreign policy that are supported empirically across all regime types. Many of these insights do not follow logically if a state-centric perspective is adopted. A critical purpose of this essay is to present evidence regarding this claim.

From the perspective of rational choice theorists, any rational actor model assumes that actors (such as decision makers) make choices that the actors believe will lead to the best feasible outcomes for them as defined by their personal values or preferences. The interests of the decision makers may or may not include enhancing something called the national interest. Decision makers connect alternatives consistently (i.e. transitively) in relations of preference or indifference; they take constraints, such as impediments in nature (e.g. where they are located geographically) and the anticipated 
actions of others into account and act in a manner that is consistent with their desires and beliefs. Such models, for instance, examine the past actions and anticipated actions of staffs, constituencies, generals, and governors in trying to understand international conflict choices. This literature, focused on the principal-agent problem, is at the core of diversionary war theories (Levy 1989; Russett 1990; Morgan and Bickers 1992; Smith 1996; Leeds and Davis 1997) and bureaucratic or interest group analyses (Allison 1972; Goldstein and Freeman 1991) of foreign affairs, and is also fundamental to the selectorate theory that assesses leader incentives under different institutional arrangements (Bueno de Mesquita et al. 2003).

These and other rational actor literatures make clear that decision makers - even central decision makers - do not have complete freedom of action and they are not in full control. They must consider whatever constraints block the path to the outcome they desire and adjust their behavior accordingly, often abandoning their most preferred goal in favor of pursuit of an attainable second or third best. Sometimes they end up with their least preferred outcome even though they chose rationally at every step along the way. Furthermore, rational decision makers do not exhaustively consider all possible alternatives if the cost of doing so exceeds the marginal gain. To do so, in fact, would be irrational as they would knowingly be wasting resources without a reasonable expectation of their recovery.

The assumption of rationality is just a starting point for constructing theories. The rationality condition sets out the theorist's view of how people are likely to select actions given their motivations or preferences; it says nothing about the content of those preferences (Zagare 1990; Jackman 1993). Constructivist models are more suitable for trying to ascertain how preferences form. Rational choice models are better suited as models of action. The contents of assumed preferences vary from theory to theory.

International relations models vary in what they assume as the ultimate goal or set of goals of their actors. These goals may be national security, national power, personal wealth, control over international rules, norms, or policies, personal power, survival in office, decision making discretion, attaining heaven in an afterlife, or a host of other possibilities. The actors may be individual citizens, elites, leaders, states, nongovernmental organizations, international governmental organizations, multinational 
corporations, or many other entities. Thus, the assumption of rationality neither limits the goals to be studied nor the identity of the actors pursuing those goals. It only limits how actors choose actions given their desires and beliefs. It certainly does not require - nor does it disallow - the notion that the state is a rational, unitary actor.

Because space is limited and the bulk of growth in the rational actor study of international conflict relies on game theory models, I focus on those models here. I divide my review along two dimensions: (1) game theoretic studies that treat states as rational unitary actors, and (2) studies that look within states at rational choices against the backdrop of domestic politics.

\section{Modeling War Choices: The Most Dangerous Foreign Policy}

Loosely speaking, we can think of war from the perspective of states in two analytic contexts. We can examine the initiation, escalation, and termination of disputes from the perspective of the war-of-attrition model or from the viewpoint of models that see war and peace as choices over risky lotteries. In a war of attrition, the good in dispute often is indivisible. In these winner-take-all contests, one party either quits at the outset or the combatants face a problem akin to an ascending price auction. When do you stop bidding if each bid incurs a sunk cost? The answer, of course, is to bid as long as the expected benefit is greater than or equal to the marginal expected cost. Naturally, this can lead to a war that persists until one or the other side has its resources completely exhausted.

Such models provide one way to look at deterrence as a policy choice. When, for instance, the anticipated costs of attack exceed the expected gains, the would-be belligerent is deterred from attacking. The problems of deterrence are, therefore, inherently problems about uncertainty. If the price each side were prepared to pay were known, then the prospective contest would end instantly. The problem of deterrence is to find the price at which a prospective belligerent can be persuaded to back down rather than attack or escalate a crisis.

Schelling (1960) addressed these issues from a rational actor perspective, with many of his insights helping to formulate American deterrence policy during the Cold War. Powell (1990) augmented Schelling's analysis, identifying the principle that 
deterrence is most likely to be effective if there is "something left to chance," that is, a risk of error sufficiently large that it makes opting for peaceful coexistence relatively attractive compared to risking the consequences of escalation. Downs and Rocke (1990; 1995) show the benefits and importance of uncertainty in shaping and containing both arms races and negotiable international disputes.

Zagare and Kilgour (2000) further advanced our understanding of deterrence issues by making clear that effective deterrence requires not only sufficient capabilities to inflict unacceptable costs in response to the initiation of belligerency, but also sufficient will to do so that threats of retaliation are credible. Here they emphasize that a deterrent threat, to be credible, must be (at least) subgame perfect; that is, a deterrence posture must be (believed to be) a best reply to the anticipated actions of other actors from each point in the game - the strategic interaction - forward. The insights from this basic noncooperative game theoretic solution concept help solve many of the dilemmas present in the earlier research on deterrence that built on Schelling's use of the game of chicken. The notion of subgame perfection eliminates strategies that rely upon threats that are not credible such as retaliatory large-scale nuclear strikes that mean national suicide. It recognizes that decision makers not only consider whether adversaries have the wherewithal to inflict unacceptable costs, but whether it is in the adversary's interest to do so down the road when it might be confronted with the need to act.

\section{Lottery Models of War or Lesser Conflict}

In lottery models of war or lesser conflict, the parties face a probability of victory and of defeat, a setting also more akin to Zagare and Kilgour's approach to deterrence. In variants that include ongoing bargaining, beliefs about those probabilities presumably change endogenously as a function of what is learned on the battlefield (Gartner 1997; Wagner 2000; Smith and Stam 2004) and so the range of bargains that are acceptable change as well (Wittman 1979). This line of reasoning, which is growing in prominence among those studying foreign policy within a rational actor framework, integrates conflict into a bargaining approach to war. Earlier lottery models understood bargaining to end once fighting began, making war outcomes more or less winner-take-all. Since few 
wars end in unconditional surrender, this newer perspective, pioneered by Wagner (2000), promises to offer a deeper understanding of how the battlefield can be used most effectively to advance a negotiated resolution of disputes.

The lottery perspective begins with a simple observation, namely, that prior to the outbreak of hostilities a range of bargains exist that are better for all parties than the expected value of war. A difficulty arises in working out the reservation price of the adversary so as to make an optimal offer that avoids fighting. Before the application of noncooperative game theory to war and peace issues, it was often thought that a bargaining range - deals falling between the adversary's reservation prices - did not exist when there was war. Recognizing that a bargaining range exists, and that its size may be fluid based on what happens on the battlefield, enhances the opportunity to model conflict policies more effectively to isolate feasible solutions.

Although the opportunity for a negotiated agreement exists, a few disputes nevertheless become wars. This seems puzzling, much as labor strikes or lawsuits seem puzzling. Of course, from the perspective of the welfare of a nation-state, by which I mean the welfare of the majority of the citizenry, war, like strikes and litigation, is always ex post inefficient. That is, knowing how a war turned out, there must have existed an ex ante, Pareto improving outcome, an outcome that at least could have avoided the transaction costs for each side associated with conducting and concluding the war.

As James Fearon (1995) has argued, war, looked at from the perspective of states, can only arise rationally if at least one of three conditions exists: an asymmetry of information, a commitment problem, or a dispute over an indivisible good.

An asymmetry of information (that is, information is incomplete and/or imperfect so that A or B or both do not know the history of prior moves made by their rival and/or do not know the value their rival or they themselves attach to alternative outcomes) can mean that one or both parties miscalculate the bargaining range and so offers are made that result in war rather than agreement. Asymmetric information, indeed, provides incentives for leaders to misrepresent the truth about their war-fighting capabilities and/or their objectives, in order to gain more. In the process, they may improve their chances of extracting more in a negotiated settlement but they also increase the risk of war and, in the end, of extracting less and losing more. Asymmetric information is seen by some as 
so important a contributor to the danger of war that it is sometimes argued that all the other rationalist explanations are just special cases of this condition: that war is, in Gartzke’s (1999) memorable phrase, in the error term.

Bueno de Mesquita and Lalman (1992) and Slantchev (2003), in a more general setting, provide models in which war can arise without uncertainty because of commitment problems. Commitment problems arise when one or the other party cannot trust the rival's statements because the rival has incentives to renege on promises. Indivisibility means that the contest is necessarily a winner-take-all affair so that there is no room for compromise, probably leaving the dispute to devolve into a war of attrition. Civil wars and other disputes over governing a given territory sometimes are indivisible. Naturally, if there is not some way to compensate a player for a loss of this sort, the problem does not have a bargaining range. One side wins and the other loses. Impatience can come into play as a source of commitment problems or uncertainty about when the expected future stream of benefits from behaving aggressively now will be sufficiently large that it is worth tolerating the short-term costs of war (Powell 1993; 1999). It remains an open question whether this consideration of impatience, or the discounted value of anticipated future costs and benefits, is a unique rational factor that can lead to war or is a special case of asymmetric information or commitment problems.

The insight that war cannot arise between states unless at least one of the rationalist conditions arises narrows the range of pathologies we as researchers must look for to understand foreign policy decisions. It helps point the way for policy makers seeking to reduce the risk of war. Since these are collectively necessary conditions, removing all of them would make war impossible. Of course, removing them is more easily said than done as they often reflect fundamental policy concerns. These rationalist explanations stand in contrast to more venerable views, such as that a balance of power (Gulick 1955; Morgenthau 1978; Waltz 1979) or an imbalance of power (Organski 1958) promotes peace and stability. To the extent that the distribution of power is known to all and all know it is known (ad infinitum, so that the distribution of power is common knowledge in game theory jargon), its degree of balance or imbalance should not determine the likelihood of peace or war. Rather, it should only matter in terms of helping to locate the bargaining range. 
If contending sides in a dispute know their chance of victory (presumably that is what is dictated by the distribution of power) and what is at stake in a war, they should find a bargaining solution that is at least as good - and possibly even better - for each of them than would be realized through fighting. They could, for instance, negotiate a settlement on the same terms as the outcome expected after a war, given the balance of power between them, while avoiding the costs of fighting. That is what it means to say that war is ex post inefficient.

Implicit in the claim that war is always ex post inefficient is the idea that the welfare of the citizenry - generally referred to as the national interest - is the same as (or at least highly correlated with) the well-being of those making war and peace choices. That is not to say that war is ever ex post efficient or that the rationalist factors are not critical, but rather to suggest that the source of uncertainty or of commitment problems may be relatively remote from decisions about war and peace when those choices are not correlated with the national interest (Maoz 1990; Goemans 2000; Chiozza and Goemans 2003; 2004). The sources of uncertainty, indivisibility, impatience, or of commitment problems may reside in the disconnection between the interests of leaders and those in whose name they lead (Bueno de Mesquita and Siverson 1995; Werner 1996). Leaders, as is well known from principal-agent models, may knowingly make choices that harm national welfare but improve their own well-being. Stalin's decision to purge his generals may be an example in point, as may John Kennedy's decision to risk nuclear war over Soviet missiles in Cuba rather than risk impeachment for failing to act even though he knew the missiles did not appreciably alter the strategic situation between the United States and the USSR (Kennedy 1969; Allison 1972).

\section{Realist Models and the Balance of Power}

Research by Fey and Ramsay (2007) investigates a well-known and commonly subscribed to notion about the distribution of power and war. Geoffrey Blainey (1988) and other realists have argued that war follows from what might be termed mutual optimism. That is, the contending sides under uncertainty collectively overestimate their individual prospects of victory so that the sum of the subjective probabilities of victory 
for the rival sides is greater than 1 . Fey and Ramsay show that even if decision makers process information inefficiently, it is not possible to support war as part of a (Bayesian perfect) equilibrium based on their mutual optimism. Such an outcome can arise only if the actors start with different prior beliefs about each other's prospects, ignoring all previous actions that reveal those beliefs even when it is in the interest of the actors or unavoidable for the actors to signal reliable information.

Niou et al. (1989; also Niou and Ordeshook 1990; 1991) provide game-theoretic models that show that an infinitely large set of power distributions are consistent with the survival of states, raising questions about foreign policy choices that depend on balancing power with rivals. Their 1989 cooperative game version implies four propositions that follow from neorealist logic: (1) essential states, that is, states that can convert at least one losing coalition into a winning coalition, never cease to exist; (2) essential states never become inessential; (3) inessential states never become essential; and (4) inessential states are eliminated from the international system. In the 1989 version, the system is, as in Waltz's (1979) theory of international politics, a self-help system. In later models (1990; 1991), Niou and Ordeshook develop noncooperative versions of the theory still more in alignment with waltz's theory. The noncooperative setting leads to modest modifications to the results. In particular, they find that with stationary strategies essential states are not eliminated and inessential states may be.

The first neorealist-implied proposition is falsified by the disappearances of the Soviet Union and Austria-Hungary. The second proposition is falsified by the decline of Spain, the Netherlands, Portugal, and countless other formerly essential states that probably no longer qualify as such. The rise of the United States and Japan in the late nineteenth and early twentieth centuries contradicts the third proposition, while the fourth proposition is contradicted by the existence of vast expanses of the contemporary world.

Kim and Morrow (1992) and Powell (1996) further demonstrate that neither equality nor preponderance of power is necessary or sufficient for war and may not even probabilistically influence the likelihood of war. Wittman (1979) shows that, because the price at which rivals will settle a dispute changes as battlefield performance changes, establishing a substantial military power advantage does not inherently make conflict resolution easier as long as demands are endogenously dependent on expectations 
regarding the probability of victory (or defeat). Indeed, Downs and Rocke (1994) highlight how a high probability of defeat can embolden individual leaders to take risks in war that would be unwarranted by a state-centric, balance of power perspective, while Bueno de Mesquita and Lalman (1992) identify specific conditions that rely on domestic political pressures under which unusually weak states - or weak actors like terrorist groups - are particularly likely to initiate violence rationally against stronger adversaries, seemingly in contradiction of standard balance of power tenets.

Powell (1991; 1993) investigates the notion that the distinction between relative and absolute gains is a critical feature of international relations. He also probed the idea that in anarchy war is the natural state of affairs and that war can only be thwarted by concerted efforts at balancing while taking into account whether military offense or defense is favored in the event of a dispute. His 1993 model depicts a world with two players which could be thought of as two states or as a bipolar international environment. The two states or players choose policies over how much to spend on the military and how much to reserve for spending on consumption. Powell demonstrates that there is a unique, Pareto-dominant equilibrium in which peace prevails and a minimal amount is spent on guns, leaving most resources for consumption. He shows how the location of this equilibrium shifts as a function of the risk-acceptance or risk-aversion of the players as well as when the offense-defense balance shifts.

Powell's analysis challenges much common thinking about foreign policy. Rather than security dominating resource allocations given the omnipresent threat of war, in equilibrium most resources go to butter which is, of course, what in fact happens in the real world. The intellectual force of Powell's analysis raises doubts about state-centric investigations as uniquely characterizing the essential features of strategic interaction in international relations. It also raises doubts about structural critiques of so-called reductionist approaches that look within states at individual behavior and domestic institutional arrangements. One may deny the importance of logical consistency, arguing that it thwarts creativity (Walt 1999), but as Powell's and others' studies intimate, to do so is to risk formulating policies on the basis of whim or personal predilection rather than the logic of situations over which life and death choices must be made. 


\section{The Political Economy of Conflict: Models Looking within the State}

The focus on states as the central actors in international politics leads to the view that what happens within states is of little consequence for understanding what happens between states. Although there have always been those who argued against these claims, the view of the state as the central player in the international arena is so strong that the English language does not provide a common word or phrase to describe international relations without invoking the nation as the key unit of analysis. Indeed, this is also true of languages at least as diverse as Chinese, French, German, Japanese, and Urdu. Anthropomorphizing the state may work as rhetoric but states do not make policy, people do; and states do not have preferences or beliefs, people do.

Strategic political economy models assess policy choices as equilibrium behavior induced in part by domestic political interests and domestic institutional structures, and often see the choice of foreign policy interactions as incentive compatible with the motivations of national leaders to maintain their personal hold on political power. Domestic institutional structures - such as the inclusiveness or exclusiveness of governance, the extent to which government is accountable and transparent or personalist and opaque, and so forth - help shape the domestic and international interplay of leaders, elites, and ordinary citizens, resulting in domestic and foreign policies that create the contours of the international environment. From many of these models, leaders try to maximize their tenure in office rather than trying to maximize national security, national wealth, or some collective notion of the national interest (Bueno de Mesquita and Lalman 1992; Fearon 1994; Werner 1996; Smith 1998; Bueno de Mesquita et al. 1999; 2003; Schultz 2001a).

If our attention is turned to national political leaders rather than to states, then it becomes apparent that fundamental policy choices - even war and peace choices - may be made without regard for citizen welfare or the national interest. One has only to reflect on Myanmar’s ruling junta, North Korea’s Kim Jong-il, or Zaire’s late Mobutu Sese-Seko to recognize that many leaders govern for their own benefit at the cost of the welfare of their subjects. So many nations have been beggared by their leaders that it is difficult to 
see how we can maintain the fiction that the national interest dictates even the most important foreign policy choices.

James Morrow (1991) provided perhaps the first formal model that linked fundamental foreign policy choices (regarding arms control agreements between the USA and the Soviet Union) to domestic conditions (inflation and unemployment). Bueno de Mesquita and Lalman (1992) suggested an early general model of international conflict that attempted to begin to unravel the role that domestic politics plays in international affairs. They proposed two variants of what they called the international interaction game (IIG). One, the Realpolitik version, attempts to capture the essential features of neorealist thought. The other, the domestic variant, in a preliminary and simple way allows for the possibility that national foreign policy goals are set by a domestic political process without specifying that process - that takes the international setting into account but that also is subject to domestic pressures and domestic political costs. Later, Bueno de Mesquita and others developed a selectorate theory of the interplay between domestic politics, domestic institutions of governance, and international politics (Bueno de Mesquita et al. 1999; 2003; Bueno de Mesquita and Smith 2008) that endogenizes resource allocations and policy choices, including war and peace decisions, within a model of domestic institutional constraints. Fearon’s (1994) and Smith’s (1998) audience costs models, discussed in the next section, further enriched the idea that domestic politics shapes even the most forceful foreign policies.

\section{The Political Economy of Regime Type}

A substantial body of political economy research has grown up around the core idea that domestic politics shapes foreign policy even on the most fundamental issues. Much of this literature focuses on the distinction between democratic and nondemocratic governing institutions, in part because of the empirical discoveries collectively known as the democratic peace and in part as a natural outgrowth of the lessons learned from structural realist investigations.

Gaubatz (1999) and Smith (2004) show that war-timing by democratic leaders is strongly influenced by the election cycle and electoral rules, providing a nuanced 
perspective on the links between foreign policy adventures and a rally-round-the-flag effect. Since timing may involve hastening or delaying war by years, with issues waxing and waning over such time periods, it is difficult to see how the system's structure can be determinative of the fundamental decision to fight or not.

Fearon (1994) suggests that democratic leaders are more constrained than autocrats to act on threats they make because of domestic audience costs if the rival fails to back down. In his model, we see that when democratic governments issue threats of war these threats should be seen as more credible by targets than comparable threats from autocrats who have low audience costs. The reason is straightforward. There are costs to going to war, but, particularly in democracies, there are also domestic political costs for threatening action to correct a perceived wrong and then failing to act on the threat. Thus, the distribution of disputes that escalate to violence should be different when a democrat is involved compared to when the parties are all nondemocratic. This leads to an interesting selection effect. Threats from democrats should increase the likelihood that rivals back down or, if the rival is not expected to back down, then negotiation rather than threats should follow from the democrat so confronted. But if the adversary is mistakenly expected to back down, democrats should be more likely to carry out their threats than are autocrats because of the audience cost tied to not doing so.

Fearon's (1994) audience costs concept has an important impact on how scholars think about conflict decision making across regime types but, as with any model, it makes some important simplifying assumptions. In particular, the model assumes that audience costs are higher in democracies than in autocracies for interpretive purposes, rather than deriving this as an endogenous property of domestic institutions. Smith (1998) endogenizes audience costs and deduces more nuanced effects, sowing conditions under which audience costs help steer democrats toward or away from war. Slantchev (2006) further extends the modeling of audience costs, making them endogenous and focusing discussion on the degree to which the threat of such costs is credible in Fearon's (1994) model.

Schultz (2001a) further expands the ideas behind audience costs by constructing a model in which there are two domestic players in one state: the incumbent government and a legitimate opposition. He shows that the existence of a legitimate domestic political 
opposition - a characteristic inherent in democracy - significantly constrains and narrows the range of foreign policy adventurism of democratic leaders in ways not experienced by nondemocrats. This should lead to a different, perhaps complementary, selection effect against conflict choices by democrats to that captured by Fearon's idea of audience costs.

Bueno de Mesquita and various co-authors (1995; 1999; 2003) develop a twodimensional "selectorate" theory of institutional arrangements. They define the selectorate as the set of people with a formal say in the selection of leaders and, more importantly, with the possibility of becoming members of a winning coalition. The winning coalition, the second institutional dimension, is the set of people whose support is essential for an incumbent leader to remain in power. The selectorate theory shows how variations in the size of a polity's selectorate and winning coalition help explain such phenomena as the empirical regularities known as the democratic peace, while also explaining the preparedness of democracies to fight wars of imperial and colonial expansion or the preparedness of democracies to overthrow foreign rivals more often than do nondemocratic interveners. This theory identifies still other selection effects that complement those found by Schultz (2001a; 2001b) and by Fearon. In particular, the selectorate perspective supports the ideas that democracies are highly selective about the conflicts they enter, requiring a near-certain expectation of victory before escalating to war.

Nowhere has the role played by domestic political institutions been more important than in the study of the impact these institutions have on war and peace. If there is one area in which it can be unequivocally stated that the political economy of international conflict has become central to policy debate, it is in the arena of the empirical regularities collectively known as the democratic peace. It is to the study of the democratic peace, then, that I now turn.

\section{The Democratic Peace}

State-centric, unitary rational actor theories lack an explanation of perhaps the most significant empirical discovery in international relations over the past several decades (Levy 1988). That is the widely accepted observation that democracies tend not to fight 
wars with one another even though they are not especially reluctant to fight with autocratic regimes.

By looking within states at their domestic politics and institutionally induced behavior, the political economy perspective provides explanations of the democratic peace and associated empirical regularities while also offering a cautionary tale for those who leap too easily to the inference that since pairs of democracies tend to interact peacefully, therefore it follows that they have strong normative incentives to promote democratic reform around the world (Bueno de Mesquita and Downs 2006).

Democratic leaders cannot afford to pursue overly risky foreign policies because they are judged by their voters primarily in terms of how good a job they do in providing public benefits, including foreign policy benefits (Lake 1992; Lake and Baum 2001; Bueno de Mesquita et al. 2003). Defeat in war is always costly for society and for democratic leaders (Bueno de Mesquita and Siverson 1995; Werner 1996; Schultz 2001a; 2001b; Chiozza and Goemans 2004.). Given the political costs of defeat, democrats are only prepared to become involved in wars when they believe at the outset that their chance of victory is high or when all efforts at negotiation (as in the period 1938-9) fail (Powell 1996; 1999; Bueno de Mesquita et al. 1999; 2003).

Autocrats, in contrast, are not retained or deposed by their essential domestic supporters primarily because of the job they do in providing successful public policies. Rather, they are judged by their ability to deliver private benefits to their winning coalition members, their cronies. Defeat in war is often less costly politically for autocrats than it is for democrats. Relatively few autocrats are overthrown and executed (though they might be sent into exile) even after defeat in war. Democratic victors pose the greatest risk to autocrats. For autocrats, winning a war - especially against nondemocrats - by spending on the war effort money they could have used to bribe cronies jeopardizes their hold on power because their cronies have no reason to remain loyal if they are deprived of their private rewards. Autocrats are more likely to be deposed - and executed - by disgruntled domestic backers for their failure to pay off key military officers or bureaucrats than they are by victorious external powers following military defeat. As a result, autocrats do not commit as many marginal resources to improving their war-victory prospects as do democrats, nor do they try as hard to find 
negotiated settlements of their disputes. Quite to the contrary, to survive in office, autocrats need to be sure that they can pay their essential supporters enough that they do not defect.

For autocrats, extra money that goes into trying to win a war is usually money that would have been better spent by using it to buy the loyalty of cronies. For democrats, saving money to bribe backers is not nearly as politically beneficial as is spending money to assure policy success, including victory in war (Bueno de Mesquita et al. 2003; 2004; Chiozza and Goemans 2004; Morrow et al. 2006).

Because democrats are selective about the circumstances under which they are prepared to fight, they almost always win the wars they initiate. In fact, research shows that democracies have won 93 percent of the wars they initiated over the past two centuries while autocrats won only about 60 percent of the time (Reiter and Stam 2002). Allowing for the small advantage gained by striking first, autocrats basically have even odds of winning when they start a war while for democrats victory is practically certain. But if two democrats are at loggerheads, then war is unlikely. Each democratic leader has similar, institutionally induced incentives (Mintz and Nehemia 1993), including an incentive to try hard if war ensues (Bueno de Mesquita et al. 1999; 2003). Each must provide policy success in order to be retained by his or her constituents. Each must believe ex ante that the probability of winning the war is a near certainty. The likelihood is practically naught that leaders of two rival democracies each believes at the same time about the same dispute that their prospects of victory are nearly certain (Fey and Ramsay 2007). When democrats do not think they are nearly certain of victory they opt for negotiations over fighting, cutting their losses and reducing the risk of deposition. Thus leaders of two democracies are unlikely to find that the circumstances are right for them to gamble on war rather than negotiate with each other. Autocrats do not face the same constraints theoretically, except when at the outset an autocrat thinks that defeat means being deposed by the victor, a circumstance that is especially unusual when the adversary does not represent a democratic government.

In the political economy account of the democratic peace, democratic leaders are not more civic minded; their actions are not shaped by superior social norms or values (Maoz and Russett 1993); and they are not inherently better at fighting wars than other 
types of political leaders (Morgan and Campbell 1991). As a result, the selectorate perspective allows us to explain not only the apparently jointly pacific behavior of democracies, but also such less attractive characteristics as the preparedness of democracies to engage in wars of colonial or imperial expansion and even the willingness of a powerful democracy to bully a much weaker democracy to capitulate to its demands rather than pay the price of fighting back, such as was the purpose behind the United States' intervention in the Dominican Republic in 1965 when its democratically elected leader, Juan Bosh, was overthrown and the Dominican military was not in a position to credibly resist. Instead, their desire to stay in office and their dependence on a large constituency shapes their choices and makes them highly selective about escalating disputes. Likewise, autocrats are not assumed to have different motivations than democrats; they just face different institutional constraints and incentives (Mintz and Nehemia 1993). State-centric approaches to international relations simply have no basis for explaining the pattern of behavior just described and yet historical, case study, and statistical analyses support the implications just reviewed.

These studies tie war and peace policy choices to a theoretic framework that places international politics squarely within the logic of domestic politics while producing propositions that confirm some system-level hypotheses while refuting others. They come at the problem with different models, but all in a common political economy framework that shares a conviction that policy decisions are strategic, taking into account expected responses by both foreign and domestic adversaries and supporters, and designed to maximize the leader's (not the state's) welfare. Each leads to some conclusions that cannot be true according to theories of international politics that treat states as undifferentiated wholes. Each has mustered empirical evidence that indicates support for the propositions that cannot hold if system-structural accounts are correct. Each bridges the divide that has in the past distinguished international politics analysis from investigations of comparative politics (Werner et al. 2003), thereby highlighting the possibility of a more integrated theory of politics.

\section{Foreign Aid, Military Intervention, and Nation Building}


One foreign policy arena in which many argue that the United States behaves differently from other countries is the domain of foreign economic assistance. It is often argued, for example, that wealthy European countries, especially the Scandinavian countries, give foreign aid out of altruistic motives. They allegedly seek to help the world's poorest people residing in the most destitute countries (Lumsdaine 1993; Noel and Therien 1995). The United States, in contrast, is often seen as making more cynical foreign aid investments based on national security considerations with only limited focus on humanitarian goals. Substantial bodies of evidence and analytic modeling, however, call this inference into question (Schraeder et al. 1998; Hook and Zhang 1998; Bueno de Mesquita and Smith 2007).

There is general agreement that foreign aid has been relatively ineffective in promoting economic growth, improved education or health care or infrastructure, or a host of other results that are thought to be the purpose behind economic assistance. Debate rages between those who think the problem is that too little money is spent on aiding the world's poor (Sachs 2005) and those who think the money is incorrectly targeted at recipient governments that too often divert it for corrupt purposes (Easterly 2002; 2006). There is a third view, which follows from a political economy approach to aid. This third view suggests that donor governments are not so naive as to fail to understand that much of their government-to-government aid will be diverted to the private uses of recipient elites. This view indicates that foreign aid is used effectively to promote its purpose, with that purpose being to trade money for policy concessions from recipient governments (Bueno de Mesquita and Smith 2007).

In the view that sees aid-for-policy deals, we can understand why, for example, the United States gives so much aid to illiberal regimes. Leaders of such regimes rely on small coalitions, who remain loyal to the incumbent in exchange for private rewards. Foreign aid provides money for private rewards. It is given by rich democracies whose incumbents are more likely to be maintained in power at the margin by obtaining policy concessions from foreign powers. Autocrats can grant those concessions more easily than can democrats, making autocrats attractive foreign aid recipients. It turns out that even the Scandinavian countries disproportionately give aid to small coalition, petty dictatorships and seemingly acquire trade concessions in return. Thus, American foreign 
aid turns out to look much like foreign aid giving by other well-to-do governments. In each case, policy concessions are obtained at the lowest price possible (this may be why foreign aid represents so little money). Poor autocracies with valuable policy concessions to offer are most likely to receive aid and, conditional on receiving aid, the more valuable the policy concession, the richer the recipient, and the larger the coalition on which the recipient relies, the more total aid it receives. Thus, countries like Egypt that have granted a major policy concession - peace with Israel - get a lot of aid while countries with less valuable policy concessions to offer, as is true for most of Africa today, receive relatively little aid whether from the United States, Japan, Scandinavia, or other donors.

While many bemoan America's foreign aid approach, it is important to recognize that it represents an equilibrium strategy. That means that American foreign policy decision makers do not have an incentive to shift to some other basis for giving aid and neither do the governments that accept aid from the United States (or other democratic countries). Four constituencies are affected by foreign aid policies and three of the four benefit from it. Donor country constituents - democratic voters - benefit because they gain policy concessions that they like from recipient regimes (Milner and Tingley 2006). Leaders in donor countries likewise benefit because the policy concessions they extract in exchange for aid - whether these concessions are related to national security, to trade, or to other policy arenas - make their constituents somewhat more likely to vote for them (ibid.). Recipient leaders benefit because they gain money with which to keep their coalition members loyal, thereby improving their own political survival prospects. The big losers generally are the people who reside in the recipient countries. They lose in two ways from foreign aid. First, their leaders give up policies that their own people favor. That is why they can sell the policy concessions. If the people naturally wanted the policies being conceded then there would be no need for donors to pay for them. And the people in the recipient countries are saddled with improved survival prospects for the very leaders who have sold them out.

Evidence based on an examination of all bilateral foreign aid deals between prospective (and actual) recipient governments and all donors who belong to the Organization for Economic Cooperation and Development (that is, the world's wealthy countries) bears out the contention that aid is better understood as money in exchange for 
policy concessions than as money to advance economic, social, or political development. Indeed, to the extent that foreign aid can be said to have an impact on political change, it is to strengthen the hand of dictators and to make regimes likely to become even more autocratic than would have been true if they did not receive economic assistance.

The same pattern of reinforcing petty dictators is found following military interventions by democracies either to shore up an existing regime or to impose regime change. In either case, democratic interveners tend to retard the prospects of democratic change, just as is true with foreign aid giving (Bueno de Mesquita and Downs 2005). As a statistical matter, this is true whether the intervener is the French government, the British government, the Dutch government, some other democracy, or the United States, after controlling for selection effects regarding how difficult the target of intervention is. As with foreign aid receipts, democratization is retarded, not advanced, by the foreign policy choices of democracies and the principles governing that retardation of democratization apply across democracies rather than being peculiar to the United States.

\section{Applied Foreign Policy Models}

Rational choices approaches have helped elucidate new insights that contribute to our understanding of foreign policy. Some of these new insights and the tools of analysis from which they are derived have also contributed meaningfully to the actual decision making process. Contrary to what some have argued, rational choice modeling and modelers are actively engaged in translating what we have learned into practical guidance in the making of foreign policy. In fact, a major initiative within the American intelligence community is centered on capitalizing more on the insights game theory reasoning and models can make to improving foreign policy tactics and strategy.

Terrorism is, of course, one of the most pressing problems confronting foreign policy decision makers. They have turned to applied game theorists in political science such as Ethan Bueno de Mesquita and Robert Powell to help them better understand terrorist motivations, responsiveness to alternative incentives and costs, organizational structures, as well as to better comprehend the efficacy of counterterror measures. Ethan Bueno de Mesquita (2005) and Bueno de Mesquita and Dickson (2007), for instance, 
isolate observable conditions that can facilitate linking negotiated concessions to the level of counterterrorism that government can expect to extract from "moderate" terrorists and that show when counterterror is expected to be effective or counterproductive. Powell (2007) has identified optimal resource allocations to protect against homeland attacks. The above cited work has proven of interest to, for instance, the Departments of Homeland Security, State, and Defense, as well as the United States Institute of Peace.

Another body of research applies rational actor models to specific policy choices. This research does not attempt to set policy goals as they are the normative responsibility of accountable, elected leaders. Instead it investigates alternative tactics and strategies in a strategic setting to enhance the prospects of fulfilling the stated policy goals. This work has moved beyond the academic research environment to become an integral part of the governmental policy analysis process. In fact, demand is sufficiently high for such modeling that at least five firms compete in this arena. All five have used versions of a forecasting and political engineering model I developed, with one, Decide BV in the Netherlands, also applying log rolling models developed by its principals (Thomson et al. 2006).

These models have been applied to thousands of specific foreign policy questions. A declassified CIA evaluation of the accuracy of one of these models states that it is accurate 90 percent of the time and that it hits the bull's-eye about twice as often as the intelligence experts who provide the data that seed the model. Academic assessments place that model's accuracy at about the same level.

Recently I developed an entirely new model for forecasting and engineering policy choices. Preliminary tests on a sample of 9 issues and more than 200 players indicate that the new model greatly outperforms my earlier model in terms of the accuracy of its predictions both at the aggregate issue level and at the individual stakeholder level. This encourages me to believe that game theory models developed by myself and others will have an even greater impact in the future (Bueno de Mesquita 2009; Thomson et al. 2006).

\section{Conclusion}


The rational actor, political economy perspective offers a significantly different explanation of international relations from that suggested by unitary rational actor theories. All of us should be cautious about dismissing received wisdom in favor of alternative accounts of history or alternative predictions about the future. Presumably, there are reasons to believe state-centric views or they would not have so many adherents and such a long history. Yet neither should we be so wedded to these older ideas that we refuse to confront their lapses in logic or their empirical failures.

Logic and empirical evidence are growing in favor of the rational actor, political economy perspective accounts for those aspects of received wisdom that are consistent with the record of history while also providing reliable explanations for facts that seem anomalous in the context of state-centric perspectives. The coming years of debate, testing, and retesting will help reveal whether the rational actor, political economy outlook supplants its older alternatives or whether it falls by the wayside. For now, I conclude that those who want to understand and advance knowledge about foreign policy, especially in conflict-prone situations, should not continue to anthropomorphize the state, but rather look at the institutions, endowments, and ease with which citizens opposed to government policies can coordinate so as to understand how domestic conditions shape the incentives of political leaders to pursue war and impose misery on their subjects or to pursue peace and advance prosperity.

\section{References}

Acemoglu, D., and Robinson. J.A. (2001) Inefficient Redistribution. American Political Science Review 95, 645-61.

Allison, G.T. (1972) The Essence of Decision. Boston: Little, Brown.

Altfeld, M.F., and Bueno de Mesquita, B. (1979) Choosing Sides in Wars. International Studies Quarterly 23 (1), 87-112.

Blainey, G. (1988) The Causes of War. New York: Free Press.

Brams, S.J. (1975) Game Theory and Politics. New York: Free Press.

Bueno de Mesquita, B. (2009) A New Model for Predicting Policy Choices. Presented at the annual meeting of the International Studies Association, New York, February 15-18. 
Bueno de Mesquita, B., and Downs, G.W. (2005) The Rise of Sustainable Autocracy (with G.W. Downs). Foreign Affairs 84 (5), 77-86.

Bueno de Mesquita, B., and Downs, G.W. (2006) Intervention and Democracy. International Organization 60 (3), 627-49.

Bueno de Mesquita, B., and Lalman, D. (1992) War and Reason: Domestic and International Imperatives. New Haven: Yale University Press.

Bueno de Mesquita, B., and Siverson, R.M. (1995) War and the Survival of Political Leaders: A Comparative Study of Regime Types and Political Accountability.American Political Science Review 89, 841-55.

Bueno de Mesquita, B., and Smith, A. (2007) Foreign Aid and Policy Concessions. Journal of Conflict Resolution 51, 251-84.

Bueno de Mesquita, B., and Smith, A. (2008) Political Survival and Endogenous Institutional Change. Comparative Political Studies 42 (2), 167-97.

Bueno de Mesquita, B., Morrow, J.D., Siverson, R.M., and Smith, A. (1999) An Institutional Explanation of the Democratic Peace. American Political Science Review 93,791-807.

Bueno de Mesquita, B., Smith, A., Siverson, R.M., and Morrow, J.D. (2003) The Logic of Political Survival. Cambridge: MIT Press.

Bueno de Mesquita, B., Morrow, J.D., Siverson, R.M., and Smith, A. (2004) Testing Novel Implications from the Selectorate Theory of War. World Politics 56, 363-88. Bueno de Mesquita, E. (2005) Conciliation, Counterterrorism, and Patterns of Terrorist Violence. International Organization 59 (1), 145-76.

Bueno de Mesquita, E., and Dickson, E. (2007) The Propaganda of the Deed: Terrorism, Counterterrorism, and Mobilization, American Journal of Political Science 51 (2), 36481.

Chiozza, G., and Goemans, H.E. (2003) Peace through Insecurity: Tenure and International Conflict. Journal of Conflict Resolution 47, 443-67.

Chiozza, G., and Goemans, H.E. (2004) International Conflict and the Tenure of Leaders: Is War Still Ex Post Inefficient? American Journal of Political Science 48, 604-19.

Downs, G.W., and Rocke, D.M. (1990) Tacit Bargaining, Arms Races, and Arms Control. Ann Arbor: University of Michigan Press. 
Downs, G.W., and Rocke, D.M. (1994) Conflict, Agency, and Gambling for

Resurrection. American Journal of Political Science 38, 362-80.

Downs, G.W., and Rocke, D.M. (1995) Optimal Imperfection? Domestic Uncertainty and Institutions in International Relations. Princeton: Princeton University Press.

Drake, H.A. (2002) Constantine and the Bishops: The Politics of Intolerance. Baltimore: Johns Hopkins University Press.

Easterly, W. (2002) The Elusive Quest for Growth: Economists, Adventures and Misadventures in the Tropics. Cambridge: MIT Press.

Easterly, W. (2006) The White Man's Burden: Why the West's Efforts to Aid the Rest Have Done So Much Ill and So Little Good. London: Penguin.

Fearon, J.D. (1994) Domestic Political Audiences and the Escalation of International Disputes. American Political Science Review 88, 577-92.

Fearon, J.D. (1995) Rationalist Explanations for War. International Organization 49, 379-414.

Fey, M., and Ramsay, K.W. (2007) Mutual Optimism and War. American Journal of Political Science 51, 4738-754.

Gartner, S.S. (1997) Strategic Assessment in War. New Haven: Yale University Press. Gartzke, E. (1999) War Is in the Error Term. International Organization 53 (3), 567-87. Gaubatz, K.T. (1999) Elections and War. Stanford: Stanford University Press. Goemans, H.E. (2000) War and Punishment. Princeton: Princeton University Press. Goldstein, J.S., and Freeman, J.R. (1991) U.S.-Soviet-Chinese Relations: Routine, Reciprocity, or Rational Expectations? American Political Science Review 85 (1), 17-35. Gulick, E.V. (1955) Europe’s Classical Balance of Power. Ithaca: Cornell University Press.

Hook, S.W., and Zhang, G. (1998) Japan’s Aid Policy since the Cold War: Rhetoric and Reality. Asian Survey 38 (11), 1051-66.

Jackman, R.W. (1993) Rationality and Political Participation. American Journal of Political Science 37 (1), 279-90.

Kennedy, R. (1969) Thirteen Days: A Memoir of the Cuban Missile Crisis. New York: W.W. Norton. 
Kim, W., and Morrow, J.D. (1992) When Do Power Shifts Lead to War? American Journal of Political Science 36, 896-922.

Lake, D.A. (1992) Powerful Pacifists: Democratic States and War. American Political Science Review 86 (1), 24-37.

Lake, D.A., and Baum, M.A. (2001) The Invisible Hand of Democracy: Political Control and the Provision of Public Service. Comparative Political Studies 34 (6), 587-621.

Leeds, B.A., and Davis, D.R. (1997) Domestic Political Vulnerability and International Disputes. Journal of Conflict Resolution 41, 814-34.

Levy, J. (1988) Domestic Politics and War, Journal of Interdisciplinary History 18, 65373.

Levy, J. (1989) The Diversionary Theory of War: A Critique. In M. Midlarsky (ed.) Handbook of War Studies. Boston: Unwin Hyman, pp. 259-88.

Lumsdaine, D.H. (1993) Moral Vision in International Politics: The Foreign Aid Regime, 1949-1989. Princeton: Princeton University Press.

Maoz, Z . (1990) Framing the National Interest: The Manipulation of Foreign Policy Decisions in Group Settings. World Politics 43, 77-110.

Maoz, Z., and Russett, B.M. (1993) Normative and Structural Causes of the Democratic Peace. American Political Science Review 87, 624-38.

Milner, H.V., and Tingley, D.H. (2006) The Domestic Politics of Foreign Aid: American Legislators and the Politics of Donor Countries. Paper presented at the Annual Meeting of the American Political Science Association, Philadelphia, September.

Mintz, A., and Nehemia, G. (1993) Why Don’t Democracies Fight Each Other? The Political Incentives Approach. Journal of Conflict Resolution 37, 487-503.

Morgan, T.C., and Bickers, K. (1992) Domestic Discontent and the External Use of Force. Journal of Conflict Resolution 36, 25-52.

Morgan, T.C., and Campbell, S. (1991) Domestic Structure, Decision Constraints and War: So Why Kant Democracies Fight? Journal of Conflict Resolution 35, 187-211. Morgenthau, H.J. (1978) Politics among Nations, revised 5th edn. Boston: McGraw-Hill. Morrow, J.D. (1991) Electoral and Congressional Incentives and Arms Control. Journal of Conflict Resolution 35, 243-63. 
Morrow, J.D., Bueno de Mesquita, B., Siverson, R.M., and Smith, A. (2006) Selection Institutions and War Aims. Economics of Governance 7 (1), 31-52.

Niou, E., and Ordeshook, P. (1990) Stability in Anarchic International Systems. American Political Science Review 84, 1207-34.

Niou, E., and Ordeshook, P. (1991) Realism versus Neoliberalism. American Journal of Political Science 35, 481-511.

Niou, E., Ordeshook, P., and Rose, G. (1989) The Balance of Power. Cambridge:

Cambridge University Press.

Noel, A., and Therien, J.-P. (1995) From Domestic to International Justice: The Welfare State and Foreign Aid. International Organization 49 (3), 523-53.

Organski, A.F.K. (1958) World Politics. New York: Knopf.

Powell, R. (1990) Nuclear Deterrence Theory: The Search for Credibility. Cambridge:

Cambridge University Press.

Powell, R. (1991) Absolute and Relative Gains in International Relations Theory.

American Political Science Review 85, 1303-20.

Powell, R. (1993) Guns, Butter, and Anarchy. American Political Science Review 87 (1), 115-32.

Powell, R. (1996) Uncertainty, Shifting Power, and Appeasement. American Political Science Review 90, 749-64.

Powell, R. (1999) In the Shadow of Power: States and Strategy in International Politics. Princeton: Princeton University Press.

Powell, R. (2007) Defending against Terrorist Attacks with Limited Resources. American Political Science Review 101, 527-41.

Reiter, D., and Stam, A., III (2002) Democracies at War. Princeton: Princeton University Press.

Russett, B. (1967) Pearl Harbor: Deterrence Theory and Decision Theory. Journal of Peace Research 2, 89-105.

Russett, B. (1990) Economic Decline, Electoral Pressure, and the Initiation of International Conflict. In C. Gochman and A. Sabrosky (eds.) The Prisoners of War? Lexington: D.C. Heath, pp. 123-40. 
Sachs, J.D. (2005) The End of Poverty: Economic Possibilities for Our Time. New York: Penguin.

Schelling, T. (1960) Strategy of Conflict. Cambridge: Harvard University Press.

Schraeder, P.J., Hook, S.W., and Taylor, B. (1998) Clarifying the Foreign Aid Puzzle: A Comparison of American, Japanese, French, and Swedish Aid Flows. World Politics 50 (2), 294-323.

Schultz, K.A. (2001a). Democracy and Coercive Diplomacy. Cambridge: Cambridge University Press.

Schultz, K.A. (2001b) Looking for Audience Costs. Journal of Conflict Resolution 45, 32-60.

Slantchev, B.L. (2003) The Power to Hurt: Costly Conflict with Completely Informed States. American Political Science Review 97 (1), 123-33.

Slantchev, B.L. (2006) Politicians, the Media, and Domestic Audience Costs. International Studies Quarterly 50, 445-77.

Smith, A. (1996) Diversionary Foreign Policy in Democratic Systems. International Studies Quarterly 40, 133-53.

Smith, A. (1998) Testing Theories of Strategic Choice: The Example of Crisis Escalation. American Journal of Political Science 43 (4), 1254-83.

Smith, A. (2004) Election Timing. Cambridge: Cambridge University Press.

Smith, A., and Stam, A.C., III (2004) Bargaining and the Nature of War. Journal of Conflict Resolution 48 (6), 783-813.

Thomson, R., Stokman, F.N., Achen, C.H., and König, T. (2006) The European Union Decides. Cambridge: Cambridge University Press.

Wagner, R.H. (2000) Bargaining and War. American Journal of Political Science 44 (3), 469-84.

Walt, S.M. (1999) Rigor or Rigor Mortis? Choice and Security Studies. International Security 23 (4), 5-48.

Waltz, K. (1979) Theory of International Politics. Reading: Addison Wesley. Werner, S. (1996) Absolute and Limited War: The Possibilities of Foreign Imposed Regime Change. International Interactions 22, 67-88. 
Werner, S., Davis, D., and Bueno de Mesquita, B. (eds.) (2003) Dissolving Boundaries: International Studies Review, Special Issue (December).

Wittman, D. (1979) How a War Ends: A Rational Model Approach, Journal of Conflict Resolution 23 (4), 743-63.

Zagare, F.C. (1977) A Game-Theoretic Analysis of the Vietnam Negotiations:

Preferences and Strategies, 1968-1973. Journal of Conflict Resolution 21 (4), 663-84.

Zagare, F.C. (1990) Rationality and Deterrence. World Politics 42 (2), 238-60.

Zagare, F.C., and Kilgour, D.M. (2000) Perfect Deterrence. Cambridge: Cambridge

University Press.

\section{Online Resources}

The Logic of Political Survival Data Source. At

www.nyu.edu/gsas/dept/politics/data/bdm2s2/Logic.htm, accessed Mar. 2009. For links to the data used in The Logic of Political Survival, including some COW data, World Bank data, Penn World Tables, immigration, human rights and other data.

Expected Utility Generation and Data Management Program (EUGene). At http://eugenesoftware.org/, accessed Mar. 2009. For country-level conflict data.

The Wilf Family Department of Politics at NYU. At http://politics.as.nyu.edu/object/AlastairSmith.html, accessed Mar. 2009. For papers and replication files for the selectorate theory project.

\section{Keywords}

Audience Costs, Balance of Power, Domestic Politics, Democratic Peace, Foreign Aid, Political Economy, Rational Actor, Selection Effects, Selectorate Theory, Unitary Actor

\section{About the Author}


Bruce Bueno de Mesquita is the Julius Silver Professor of Politics and Director of the Alexander Hamilton Center for Political Economy at New York University as well as a Senior Fellow at the Hoover Institution, Stanford University. His current research focuses on the political economy of development and foreign policy. 